\title{
Memórias e resistências de assistentes sociais contra a ditadura
}

\author{
Daniela Neves* e Tânia Maria Ramos de Godoi Diniz** (Texto ) \\ Rafael Werkema*** (Imagens****)
}

O Serviço Social na história da ditadura civil militar. Este é o tema desta mostra fotográfica, apresentada por meio do Projeto Serviço Social, Memórias e Resistências contra a Ditadura, neste espaço de "diálogo em imagens".

O projeto foi idealizado e realizado a muitas mãos pelo Conselho Federal de Serviço Social (CFESS). Seus primeiros esboços foram discutidos na gestão "Tempo de Luta e Resistência" (2011-2014) e finalizados na gestão "Tecendo na luta a manhã desejada" (2014-2017).

O projeto teve como objetivo recuperar e tornar pública a memória daqueles/as assistentes sociais e estudantes de Serviço Social cujos direitos foram violados nos trágicos e violentos acontecimentos da ditadura empresarial militar no Brasil. Pessoas que lutaram pela liberdade e pela justiça ao lado de muitos/as outros/as combatentes, que resistiram e sobreviveram às mais cruéis violações de direitos humanos e contribuíram na luta pela democracia no país.

Antes de apresentarmos a mostra fotográfica, vale recuperar, de maneira breve, como foi desenvolvido o projeto Serviço Social, Memórias e Resistências contra a ditadura e mostrar as nuances da construção de sua identidade visual, fundamental nas diferentes formas e atividades que evocam

\footnotetext{
* Assistente social e conselheira vice-presidente do Conselho Federal de Serviço Social (CFESS) Gestão "É de batalhas que se vive a vida" (2017-2020). Professora Doutora do Departamento de Serviço Social da Universidade Federal do Rio Grande do Norte (UFRN). Correspondência: CFESS - Setor Comercial Sul (SCS): Quadra 2, Bloco C, Ed. Serra Dourada, Salas 312/318. E-mail:<daniela@cfess.org.br>.

** Assistente social e conselheira do Conselho Federal de Serviço Social (CFESS) Gestão "É de batalhas que se vive a vida" (2017-2020). Professora Adjunta do Departamento de Serviço Social da Universidade Federal de São Paulo (Unifesp). Correspondência: CFESS - Setor Comercial Sul (SCS): Quadra 2, Bloco C, Ed. Serra Dourada, Salas 312/318. E-mail: <tania@cfess.org.br>.

*** Assessor de Comunicação do Conselho Federal de Serviço Social (CFESS). Graduado em Comunicação Social/ Jornalismo pela Fundação Mineira de Educação e Cultura (Universidade Fumec) e técnico em Comunicação Visual pelo Instituto de Arte e Projeto de Belo Horizonte (Inap). Correspondência: CFESS - Setor Comercial Sul (SCS): Quadra 2, Bloco C, Ed. Serra Dourada, Salas 312/318. E-mail: <comunicacao@cfess.org.br>.

**** Intervenções gráficas digitais sobre fotografias / ilustrações, fotocolagens e recortes.
} 


\section{Revistg all paUtg}

\} MEMÓRIAS E RESISTÊNCIAS DE ASSISTENTES - NEVES, D.; DINIZ, T. M. R. G.; WERKEMA, R.

DOI: $10.12957 /$ REP.2017.32733

o caráter de denúncia e resistência ${ }^{1}$, de maneira criativa e contestatória. O projeto evidencia a relação intrínseca entre conteúdo político/editorial e conteúdo visual/gráfico, objetivo deste diálogo em imagens: as imagens fotografias e ilustrações - contribuíram e contribuem significativamente na interpretação e expressão do que foi proposto, que é contar as histórias de assistentes sociais e estudantes, que sofreram violações de direitos e lutaram contra o arbítrio da ditadura, que perdurou por 21 anos (1964 a 1985).

Seu lançamento, em maio de 2013, contou com divulgação online da proposta do projeto e um roteiro para que assistentes sociais que sofreram violações de direitos na ditadura fizessem o seu registro.

Esse formulário, cujo preenchimento realizado por diversas/os assistentes sociais - ex-presos/presas políticos/as - possibilitou-nos conhecer, por meio de seus depoimentos, histórias de resistência e sobrevivência. Alguns depoimentos foram realizados de forma diferente: seja por meio de um texto livre, elaborado pelo/a autor/a, ou pessoalmente, durante um evento da categoria (43ํㅡㄹ Encontro Nacional do Conjunto CFESS-CRESS, Brasília/ DF, 2014), em uma mesa-redonda que contou com depoimentos de cinco assistentes sociais que vivenciaram os horrores dos tempos de chumbo no Brasil. Tivemos também transcrições de palestras ou de relatos paras as Comissões da Verdade e depoimentos escritos, que foram editados e colocados em um vídeo.

O tempo dispendido nessa primeira parte do projeto, expresso nas dificuldades encontradas pelos/as assistentes sociais para deporem sobre esse passado de terror e sangue, que não está imerso nas poeiras do esquecimento, mostrou-nos quão forte foi o sequestro de seus corpos e mentes nos anos da ditadura que assombrou o país. São marcas de sofrimentos que não podem ser eliminadas. Tratava-se de um material denso, bruto, que precisava ser apresentado à categoria profissional.

Em 2016, já tínhamos um número considerável de depoimentos captados de diferentes formas. Assim, no $15^{\circ}$ Congresso Brasileiro de Assistentes Sociais (CBAS), realizado em Olinda (PE), organizamos uma exposição sobre o projeto, em forma de painéis, reunindo trechos dos depoimentos e fotos que havíamos recebido até então.

Mas a ideia do projeto era não só contar estas histórias e dar visibilidade para quem as viveu, mas trazê-las para as novas gerações, reafirmando que relembrar é preciso, para que a história não se repita.

Nesse sentido, a exposição buscou reproduzir e produzir sensações, ao ambientarmos o local com músicas sobre resistência e iluminação especial, além de ilustrarmos as paredes com os depoimentos e com figuras inspiradas em cartazes contra a tortura, em fotografias históricas e em imagens que procuravam transmitir a dor, o sofrimento e a luta dos/as assistentes sociais e estudantes. Também em 2016, essa exposição foi disponibilizada

${ }^{1}$ Conforme afirma um dos pressupostos/princípios da Política de Comunicação do Conjunto CFESS-CRESS: "valorizar a dimensão política da comunicação usá-la em seu caráter de denúncia e resistência". (2007, pag. 8). 


\section{hevigta all pautg}

\} MEMÓRIAS E RESISTÊNCIAS DE ASSISTENTES - NEVES, D.; DINIZ, T. M. R. G.; WERKEMA, R. \} DOI: $10.12957 /$ REP.2017.32733

pelo CFESS no $15^{\circ}$ Encontro Nacional de Pesquisadores/as em Serviço Social (Enpess) em Ribeirão Preto (SP).

Em 2017, encerramos o projeto com o lançamento do livro Depoimentos, que traz os relatos na íntegra, documentos históricos, fotografias, ilustrações e outros tipos de imagens que dialogam diretamente com o conteúdo. O livro é acompanhado de um DVD com o vídeo passado na exposição do CBAS (e do Enpess), com outro material audiovisual que captou a emoção dos/as presentes ao adentrarem o espaço da exposição e com um arquivo com matérias publicadas pelos CRESS sobre o assunto.

É desse livro e de todo o Projeto Serviço Social, Memórias e Resistências contra a ditadura a inspiração para essa sessão fotográfica que será apresentada nas próximas páginas. Seu componente gráfico recuperou alguns rostos da resistência e rememorou os terrores da tortura, por meio de fotografias e ilustrações.

Assim, dividimos esta mostra em três momentos:

1. Faces da resistência

As pessoas que participaram do projeto e enviaram seus relatos têm rostos. São de carne e osso. Seus corpos e mentes foram violentados de maneiras tão cruéis, que fica difícil, por vezes, imaginar tais violações. Violências que deixaram marcas, muitas delas físicas.

Assim, a partir de documentos enviados pelos/as participantes do projeto e do material de pesquisa que conseguimos reunir, buscamos, por meio de intervenções gráficas digitais sobre fotografias originais, ressaltar que estas marcas perduram, sejam em cicatrizes ou expressões faciais.

Ainda neste primeiro momento, construímos, a partir das fotografias disponíveis no livro Mulheres de Ibiúna, um painel com as estudantes de Serviço Social que participaram do $30^{\circ}$ Congresso da União Nacional dos Estudantes (UNE). Na ocasião, quase mil estudantes sofreram violência psicológica e física, repressão e acabaram na prisão.

\section{Relatos selvagens}

A partir de ilustrações inspiradas em cartazes e imagens produzidas à época, e, principalmente, dos relatos chocantes sobre a tortura, buscamos, nesse segundo momento, mostrar os horrores das violações de direitos. $\mathrm{O}$ vermelho de sangue (mas também de luta) é constante em todas as imagens que, por vezes, demonstram dor e desespero. Mostramos também os torturadores que, na visão de quem sofreu tortura, significavam a morte fardada, com toda sua ironia e crueldade. Militares que quebraram corpos e mentes em atos violentos e com objetos.

\section{Relembrar é preciso}

Neste último momento, reafirmamos, por meio de fotografias, um dos objetivos do projeto, que foi o de contar às novas gerações de assistentes 


\section{ReVistg QIII PaUtg}

\} MEMÓRIAS E RESISTÊNCIAS DE ASSISTENTES - NEVES, D.; DINIZ, T. M. R. G.; WERKEMA, R. \}

DOI: $10.12957 /$ REP.2017.32733

sociais a história da ditadura civil-militar no Brasil, para que a mesma não volte a ocorrer. Defender a democracia é compromisso ético da categoria.

Ilustrar o projeto não foi tarefa fácil. Em diversos momentos, a produção gráfica surgiu para completar, ou até mesmo "verbalizar", aquilo que não conseguiu ser dito. Ou que foi dito, mas precisava ser escancarado. Falamos de um período difícil, do qual muitas pessoas tentaram, em vão, esquecer. Outras não conseguiram falar.

Mas firmamos o compromisso com a história de luta destes sujeitos. Tornamos pública a experiência trágica daqueles/as que tiveram seus direitos violados na ditadura militar e trouxemos, para as novas gerações do Serviço Social, um período de terror vivido no país, não só como uma denúncia, mas como um alerta contra a ignorância histórica e política que ceifou muitas vidas, projetos e sonhos. E uma contribuição para o enfrentamento do autoritarismo, da opressão e da criminalização das lutas por uma sociedade igualitária.

Texto e imagem, em uma relação simbiótica, para contar histórias de profissionais e estudantes comprometidos/as com as lutas da classe trabalhadora, com a liberdade e a justiça social.

DOI: 10.12957/rep.2017.32733

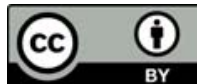

A Revista Em Pauta: Teoria Social e Realidade Contemporânea está licenciada com uma Licença Creative Commons Atribuição 4.0 Internacional. 


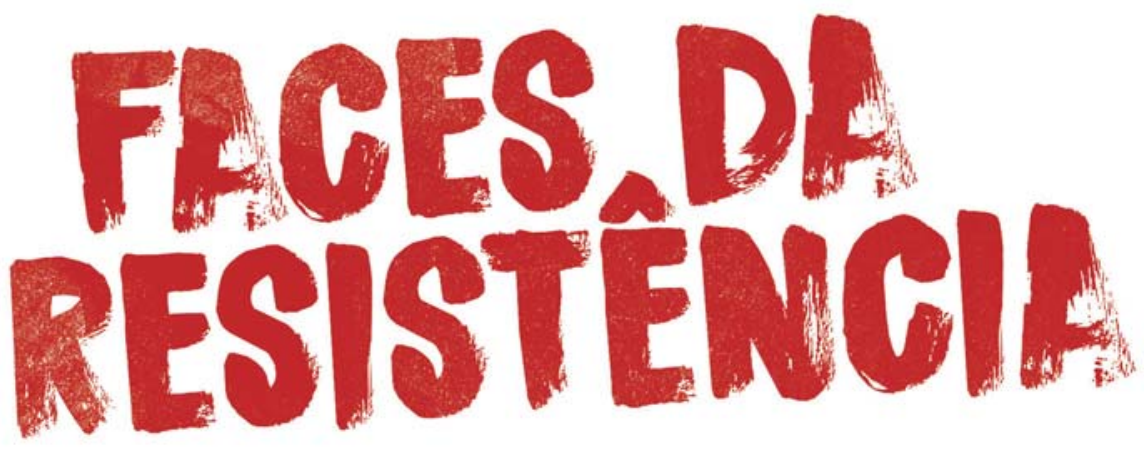

01. Faces da Resistência

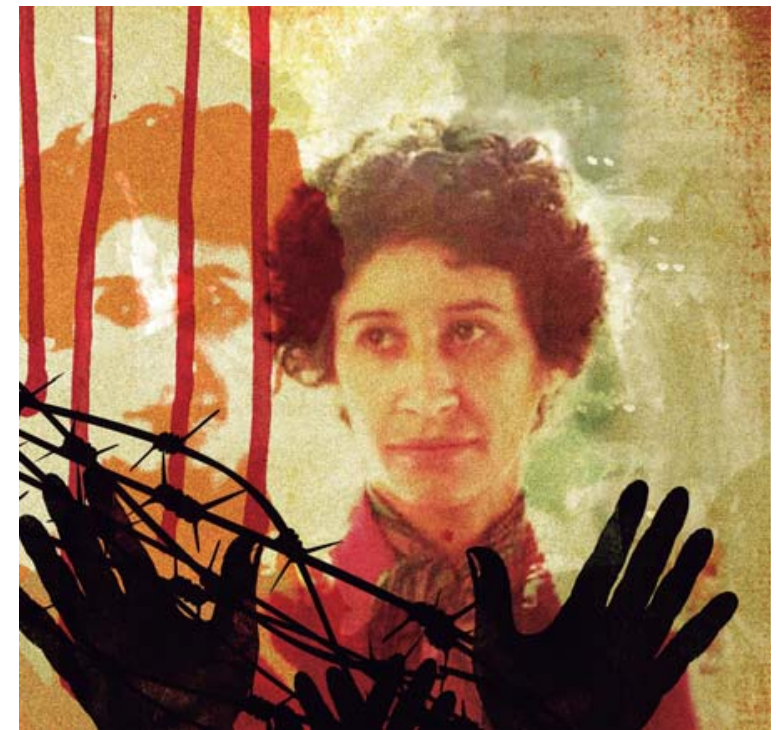

02. Ana Maria Ramos Estêvão - Assistente social. Formada pela PUC-SP (1976), integrou o diretório acadêmico da Faculdade de Serviço Social. Ofereceu apoio logístico a militantes do Grupo Tático Armado da Ação Libertadora Nacional. Design: Rafael Werkema - intervenção gráfica digital/fotocolagem/ilustração sobre fotografia original. 


\section{ReVigtg all paltg}

\} MEMÓRIAS E RESISTÊNCIAS DE ASSISTENTES - NEVES, D.; DINIZ, T. M. R. G.; WERKEMA, R.

DOI: $10.12957 /$ REP.2017.32733

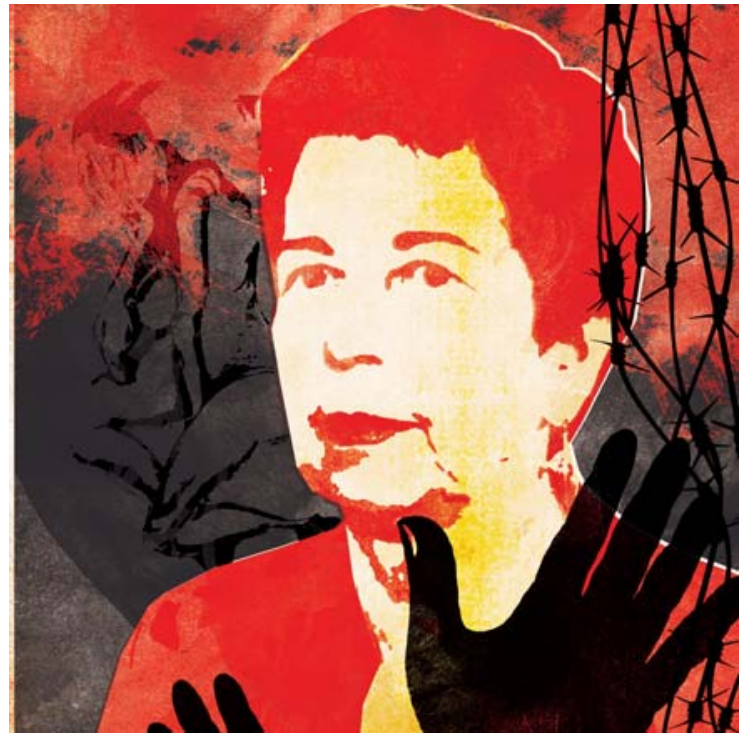

03. Ana Maria Santos Rolemberg - Assistente social. Formada pela UFS (1968), integrou o diretório acadêmico da Faculdade de Serviço Social, participou da Ação Popular do Partido Comunista do Brasil (PC do B). Design: Rafael Werkema - intervenção gráfica digital/fotocolagem/ilustração sobre fotografia original.

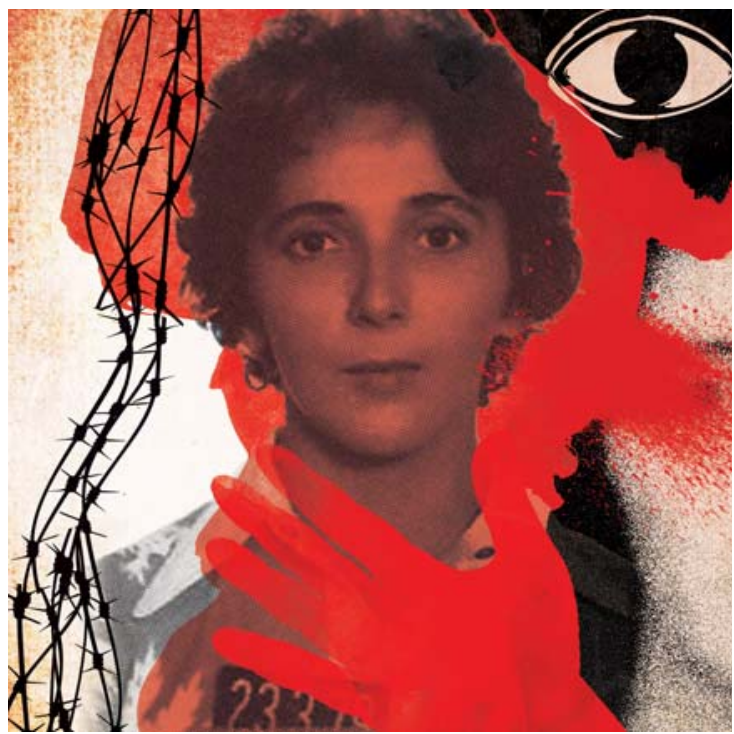

04. Cândida Moreira Magalhães - Assistente social. Formada pela UFC (1971), participou ativamente das atividades do centro acadêmico da Universidade e integrou a Juventude Estudantil Católica. Design: Rafael Werkema - intervenção gráfica digital/fotocolagem/ ilustração sobre fotografia original. 


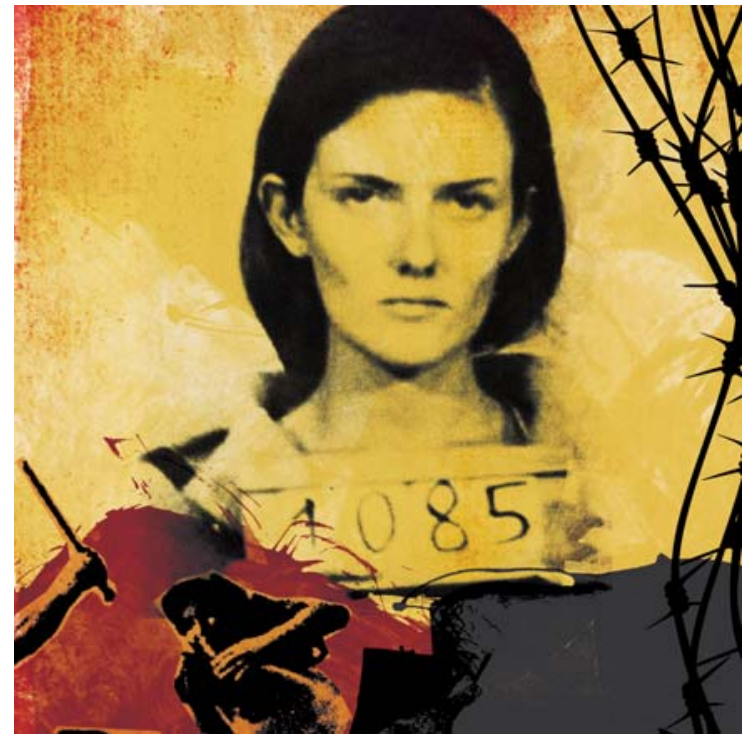

05. Ana Maria Froés Batalha - Assistente social. Formada na UFBA pela UCSal, integrou o movimento estudantil em Serviço Social, participou da Ação Católica e foi simpatizante da Ação Popular. Design: Rafael Werkema - intervenção gráfica digital/fotocolagem/ ilustração sobre fotografia original.

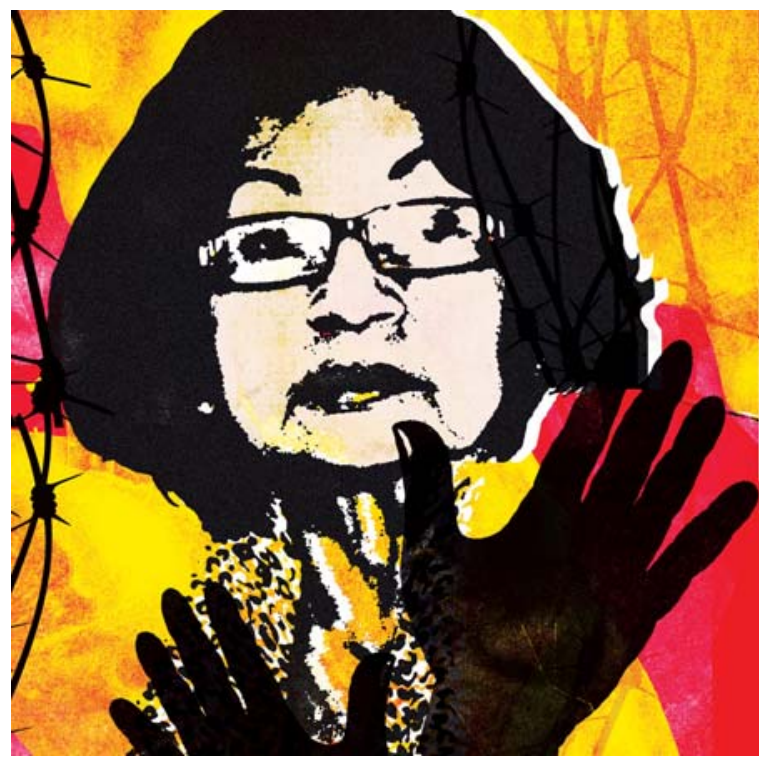

06. Joaquina Barata Teixeira - Assistente social. Formada pela UFPA, foi presidenta do diretório acadêmico de Serviço Social. Design: Rafael Werkema - intervenção gráfica digital/fotocolagem/ilustração sobre fotografia original. 
\} MEMORIAS E RESISTÊNCIAS DE ASSISTENTES - NEVES, D.; DINIZ, T. M. R. G.; WERKEMA, R. \} DOI: $10.12957 /$ REP.2017.32733

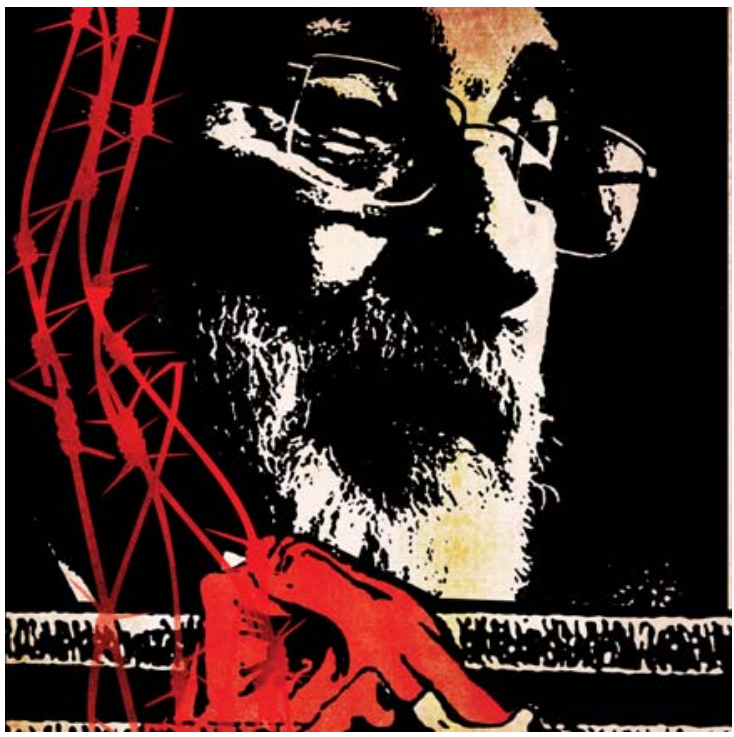

07. José Paulo Netto - Assistente social. Formado pela UFJF (1966-1969), integrou o Partido Comunista Brasileiro (PCB). Design: Rafael Werkema - intervenção gráfica digital/ fotocolagem/ilustração sobre fotografia original.

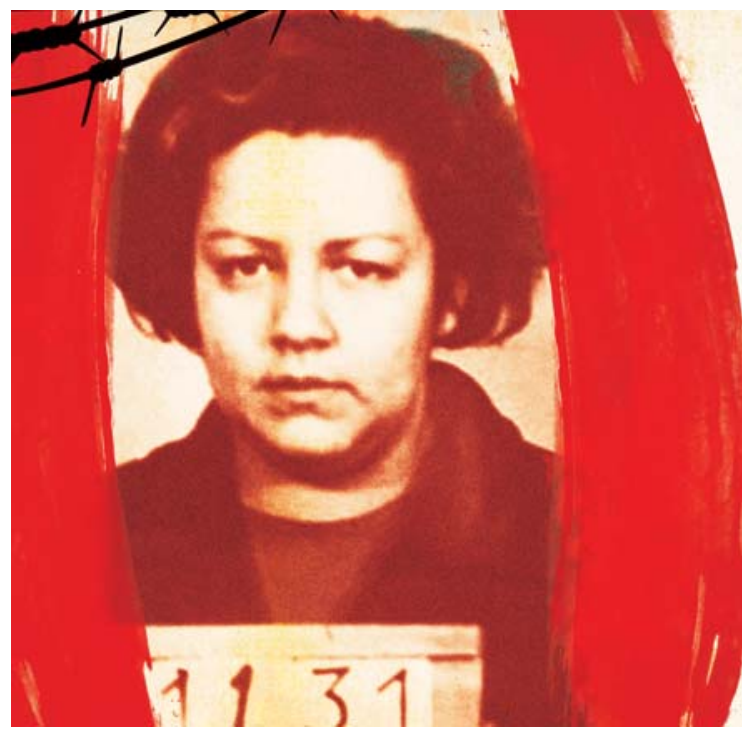

08. Maria Beatriz Costa Abramides - Assistente social. Formada pela PUC-SP (1971), fez parte do movimento estudantil em Serviço Social, pertenceu à Ação Popular e integrou o Grupo de Trabalho Revolucionário. Design: Rafael Werkema - intervenção gráfica digital/fotocolagem/ilustração sobre fotografia original. 


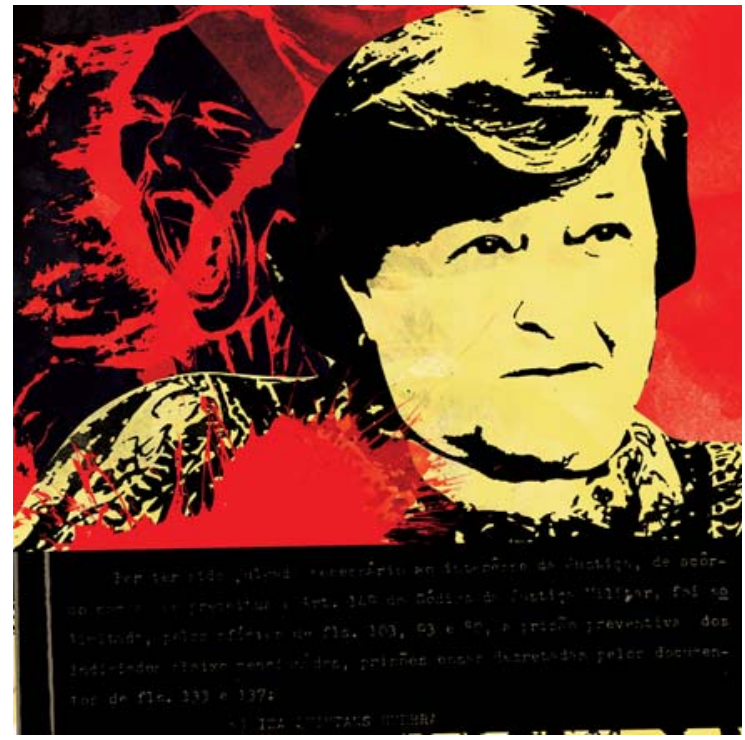

09. Iza Guerra Labelle - Assistente social. Integrou a Juventude Universitária Católica e a Ação Popular. Design: Rafael Werkema - intervenção gráfica digital/fotocolagem/ ilustração sobre fotografia original.

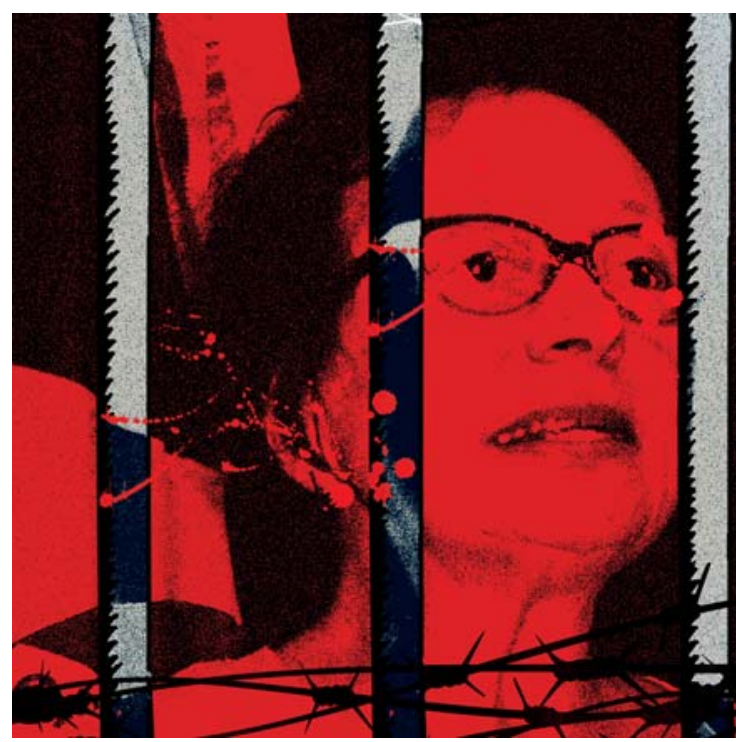

10. Maria Rosângela Batistoni - Assistente social. Formada pela PUC-MG (1972), militou na Ação Popular e, posteriormente, se aproximou da Organização de Combate MarxistaLeninista (OCML-POLOP). Design: Rafael Werkema - intervenção gráfica digital/ fotocolagem/ilustração sobre fotografia original. 


\section{ReVistg QII P.Utg}

\} MEMÓRIAS E RESISTÊNCIAS DE ASSISTENTES - NEVES, D.; DINIZ, T. M. R. G.; WERKEMA, R.

DOI: $10.12957 /$ REP.2017.32733

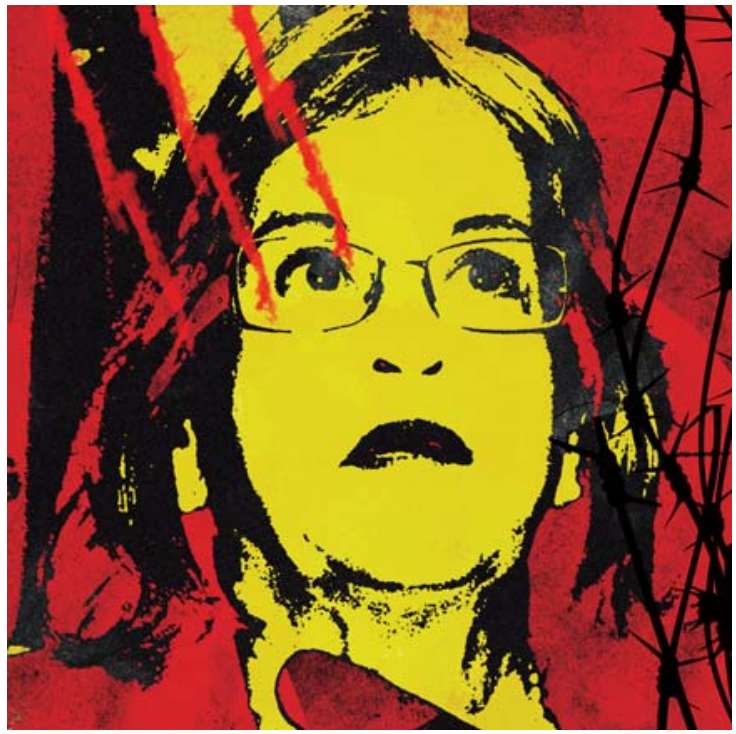

11. Marilda Vilela lamamoto - Assistente social. Formada pela UFJF (1967-1971), participou da Ação Católica, Juventude Estudantil Católica, Juventude Universitária Católica, além de integrar o diretório acadêmico da Faculdade de Serviço Social. Design: Rafael Werkema - intervenção gráfica digital/fotocolagem/ilustração sobre fotografia original.

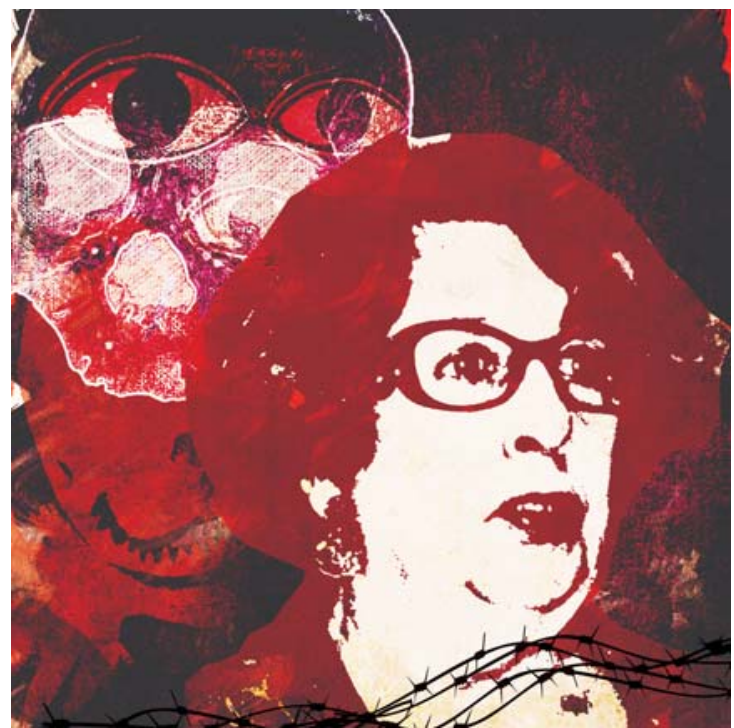

12. Mariléia Venâncio Porfírio - Assistente social. Formada pela UFJF (1969), foi presidenta do diretório acadêmico da Faculdade de Serviço Social e participou da Ação Popular. Design: Rafael Werkema - intervenção gráfica digital/fotocolagem/ilustração sobre fotografia original. 


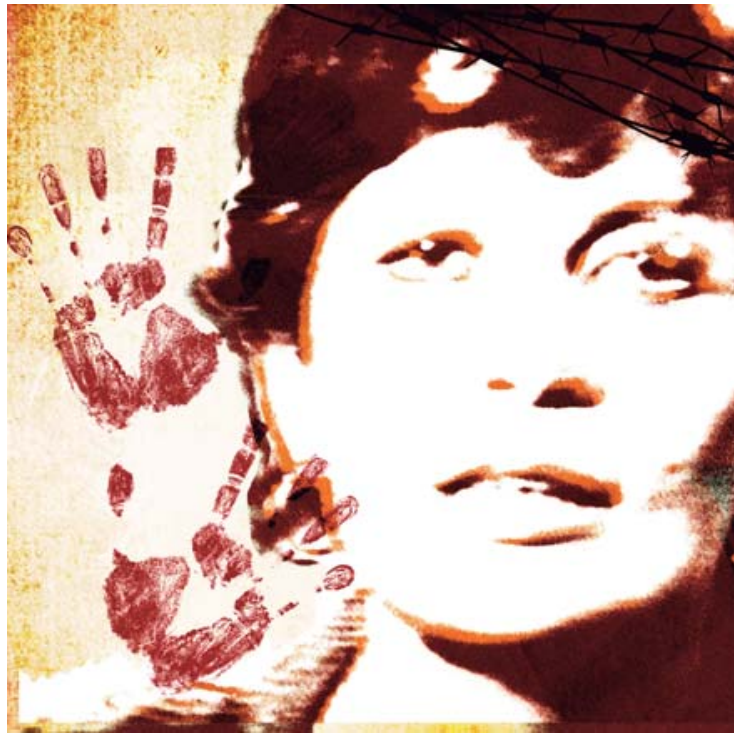

13. Rosalina Santa Cruz-Assistente social. Formada pela PUC-SP, militou no movimento estudantil, foi presa por um ano. Integrou o movimento da Anistia. Seu irmão Fernando Santa Cruz continua desaparecido em decorrência da ditadura. Design: Rafael Werkema - intervenção gráfica digital/fotocolagem/ilustração sobre fotografia original.

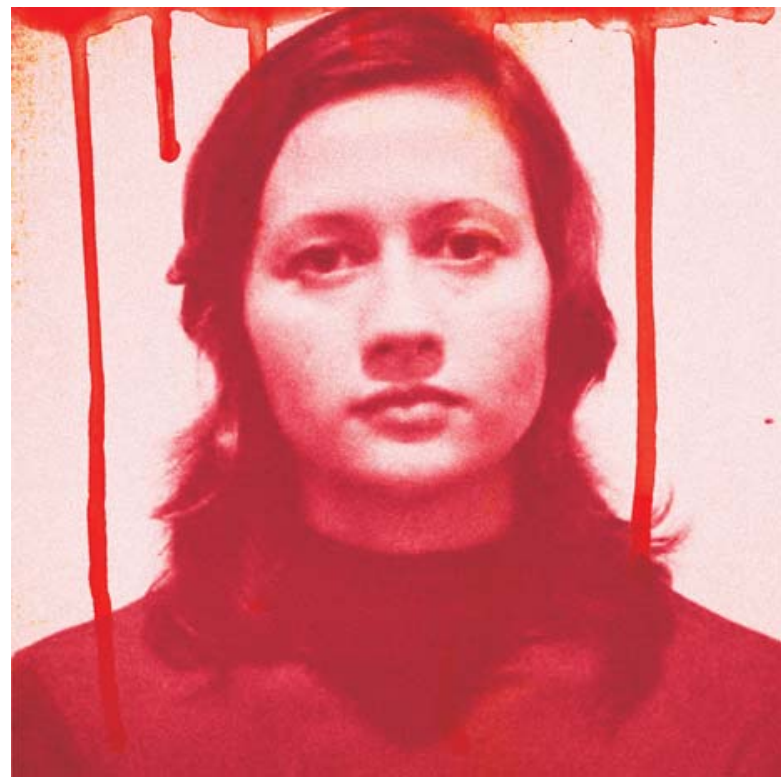

14. Rute Gusmão - Assistente social. Formada pela PUC-RJ, integrou a Ação Cristã de Acadêmicos, a União Cristã de Estudantes do Brasil e a Ação Popular. Design: Rafael Werkema - intervenção gráfica digital/fotocolagem/ilustração sobre fotografia original. 


\section{ReVigtg all paltg}

\} MEMÓRIAS E RESISTÊNCIAS DE ASSISTENTES - NEVES, D.; DINIZ, T. M. R. G.; WERKEMA, R.

DOI: $10.12957 /$ REP.2017.32733

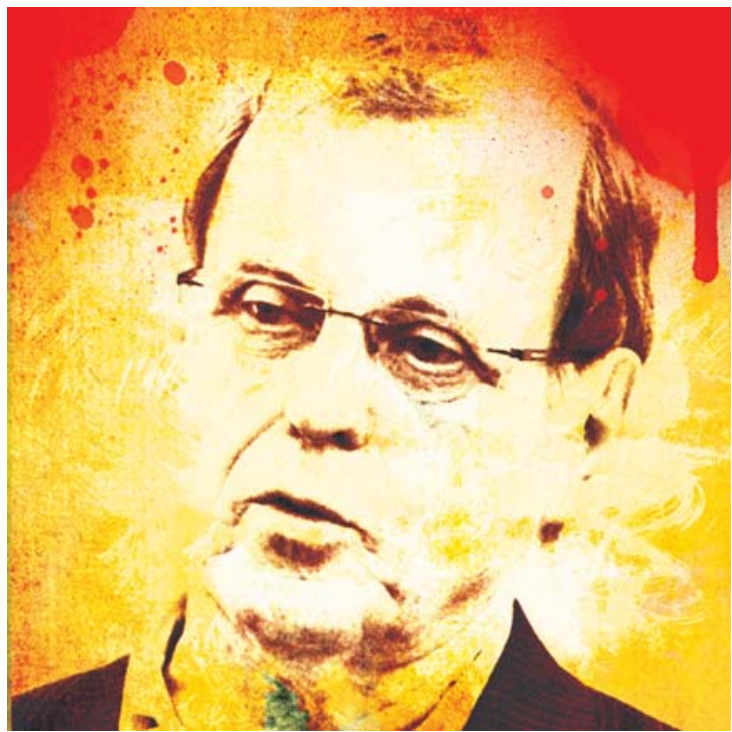

15. Vicente de Paula Faleiros - Assistente social. Formado pela Universidade de Ribeirão Preto (1964), integrou o movimento estudantil de Serviço Social, a Ação Popular (AP) e o Partido Comunista Brasileiro (PCB). Design: Rafael Werkema - intervenção gráfica digital/fotocolagem/ilustração sobre fotografia original.

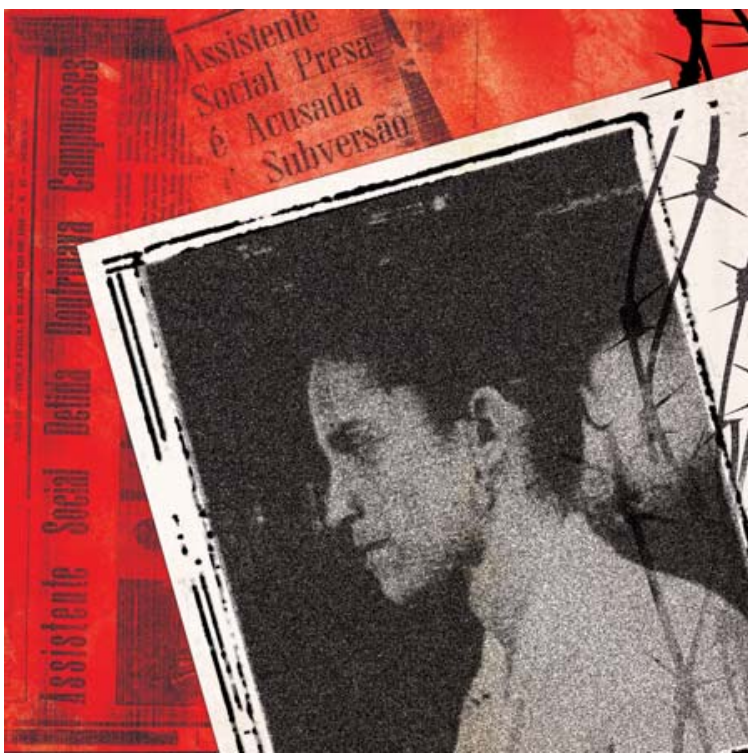

16. Maria Lúcia de Carvalho Souto - Assistente social. Formada pela UFAL, militou no movimento estudantil de Serviço Social, participou da Ação Popular e integrou o Partido Comunista do Brasil (PC do B). Design: Rafael Werkema - intervenção gráfica digital/ fotocolagem/ilustração sobre fotografia original. 


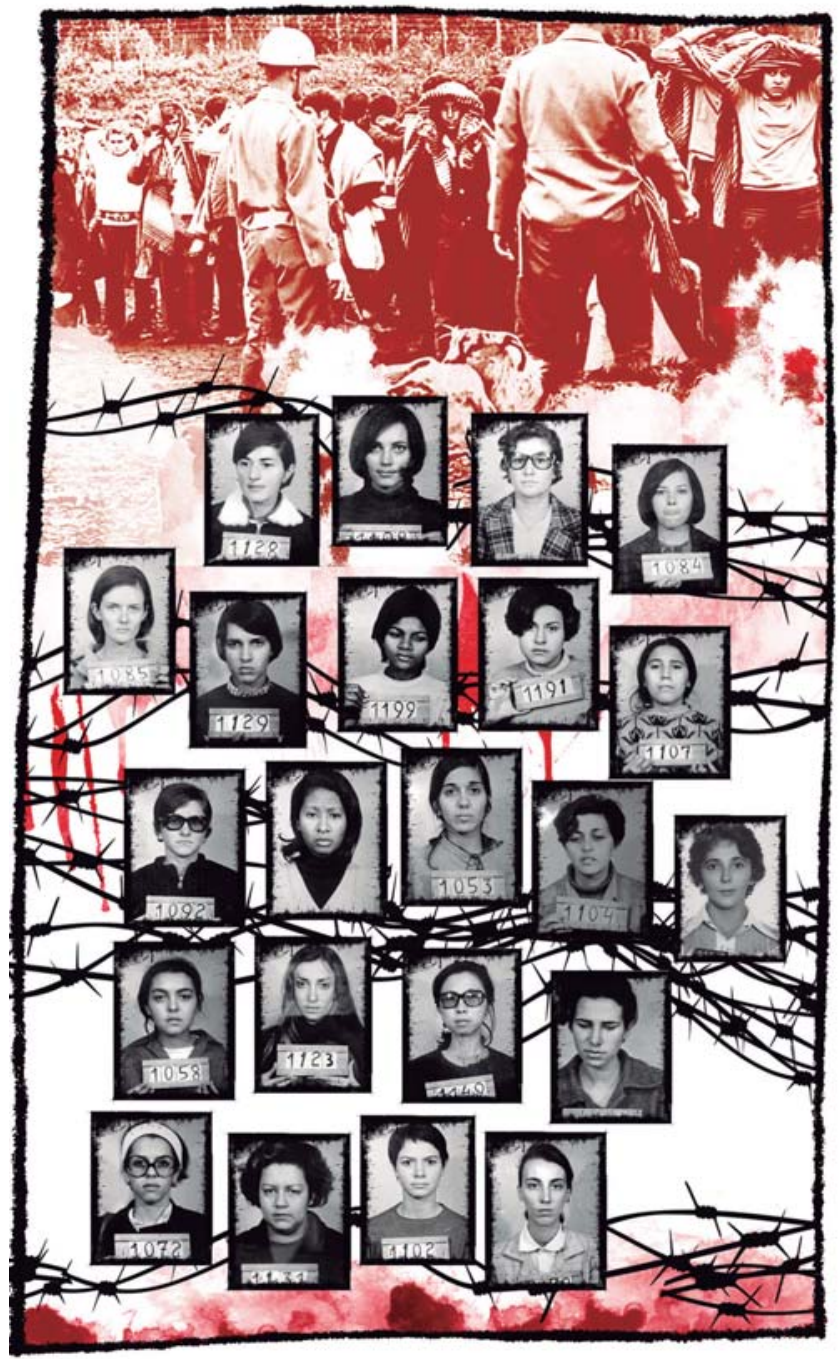

17. Painel Mulheres de Ibiúna - Da esquerda para direita: Cacilda Filomena de Castro; Aurivanda Almeida da Silva; Celia Zanqueta; Elaine Gonzaga Negreiros; Ana Maria Froes Batalha; Elizabeth Schimidt de Andrade; Elze Maria dos Santos; Estela Maria Ourique da Silva; Guilhermina de Souza Bezerra; Maria da Graça Ferro Baima Pereira; Miramar da Costa Correia; Maria Regina Sampaio Terra; Marcia Vera de Vasconcelos; Candida Moreira Magalhães; Maria Tereza Cardoso; Marlene do Amaral Simonetti; Rosa Haruko Tane; Rosemary Cardoso; Verônica Aguiar dos Santos; Maria Beatriz da Costa Abramides; Clarice Chonchol; Helena Costa Lopes. Design: Rafael Werkema fotocolagem sobre imagens do livro As Meninas de Ibiúna, disponível em http:// www.documentosrevelados.com.br/repressao/as-meninas-de-ibiuna-152-fotografiasdasestudantes-presas-no-congresso-de-ibiuna/ 


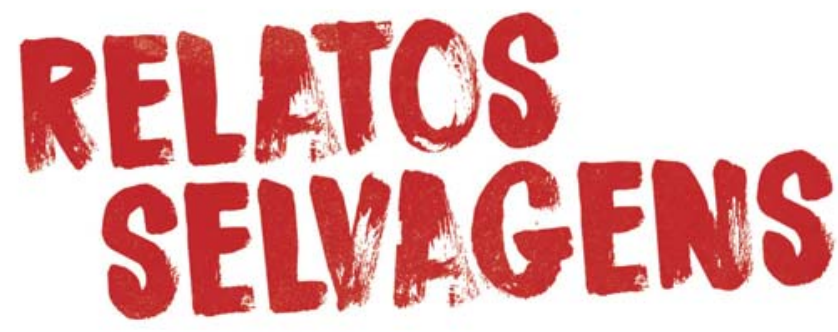

18. Relatos Selvagens

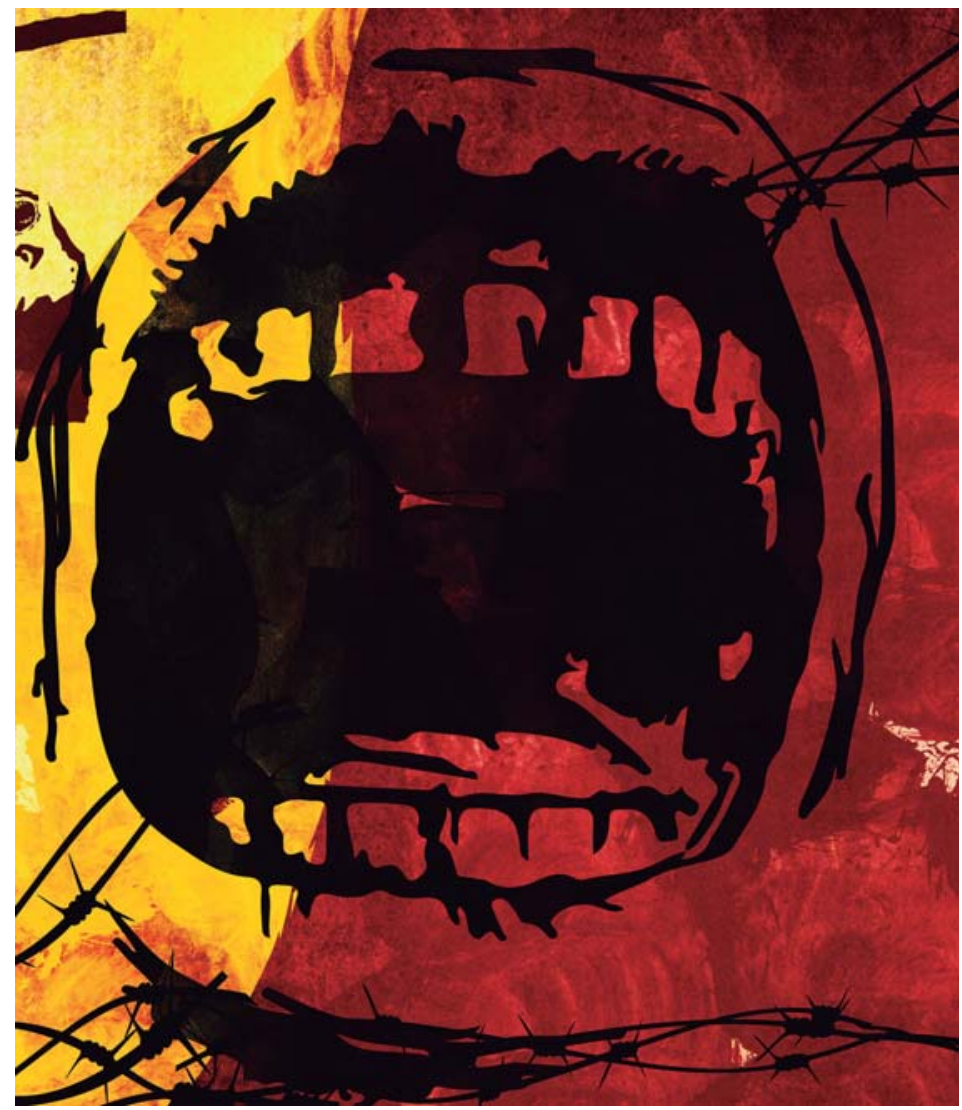

19. O Grito. Design: Rafael Werkema - ilustração digital/fotocolagem. 


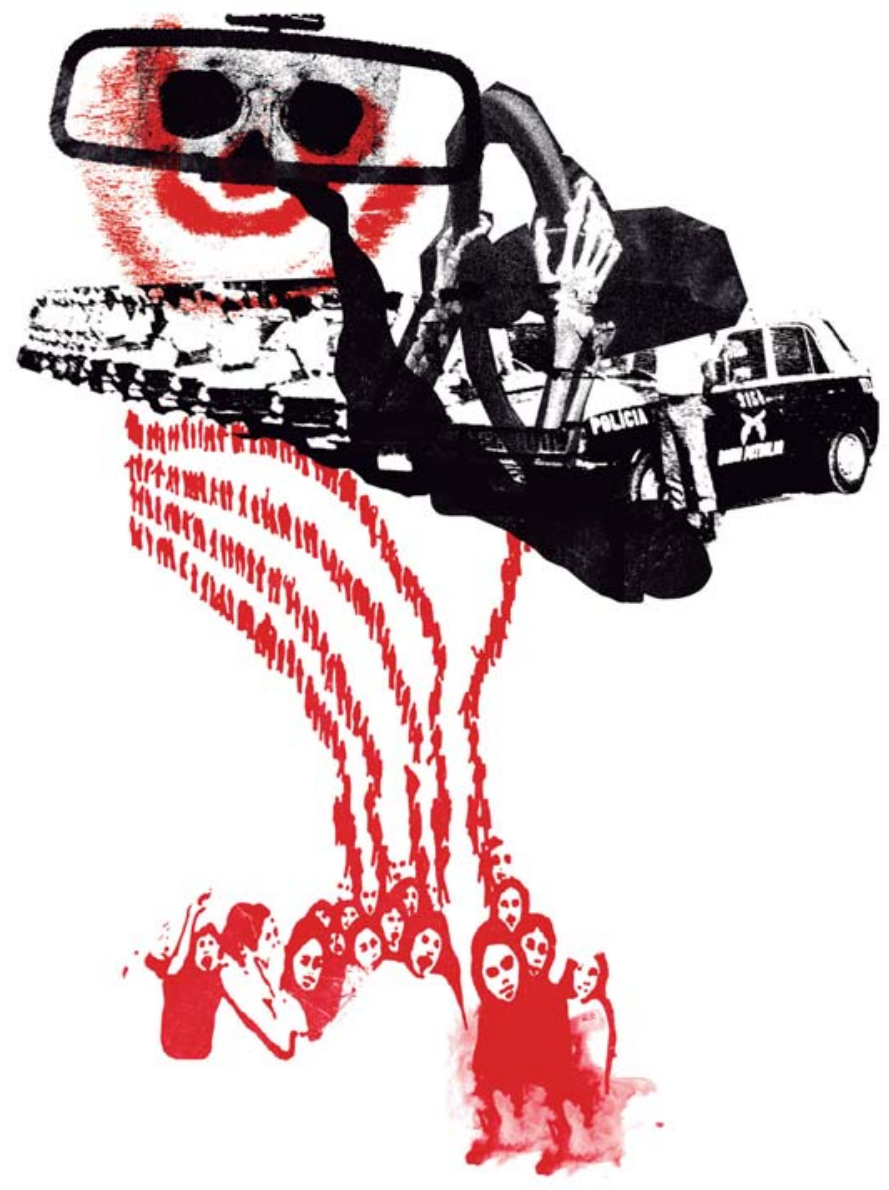

20. Corcéis da morte. Design: Rafael Werkema - ilustração digital/fotocolagem. 


\section{ReVistg all pgUtg}

\} MEMORIAS E RESISTÊNCIAS DE ASSISTENTES - NEVES, D.; DINIZ, T. M. R. G.; WERKEMA, R.

DOI: $10.12957 /$ REP.2017.32733

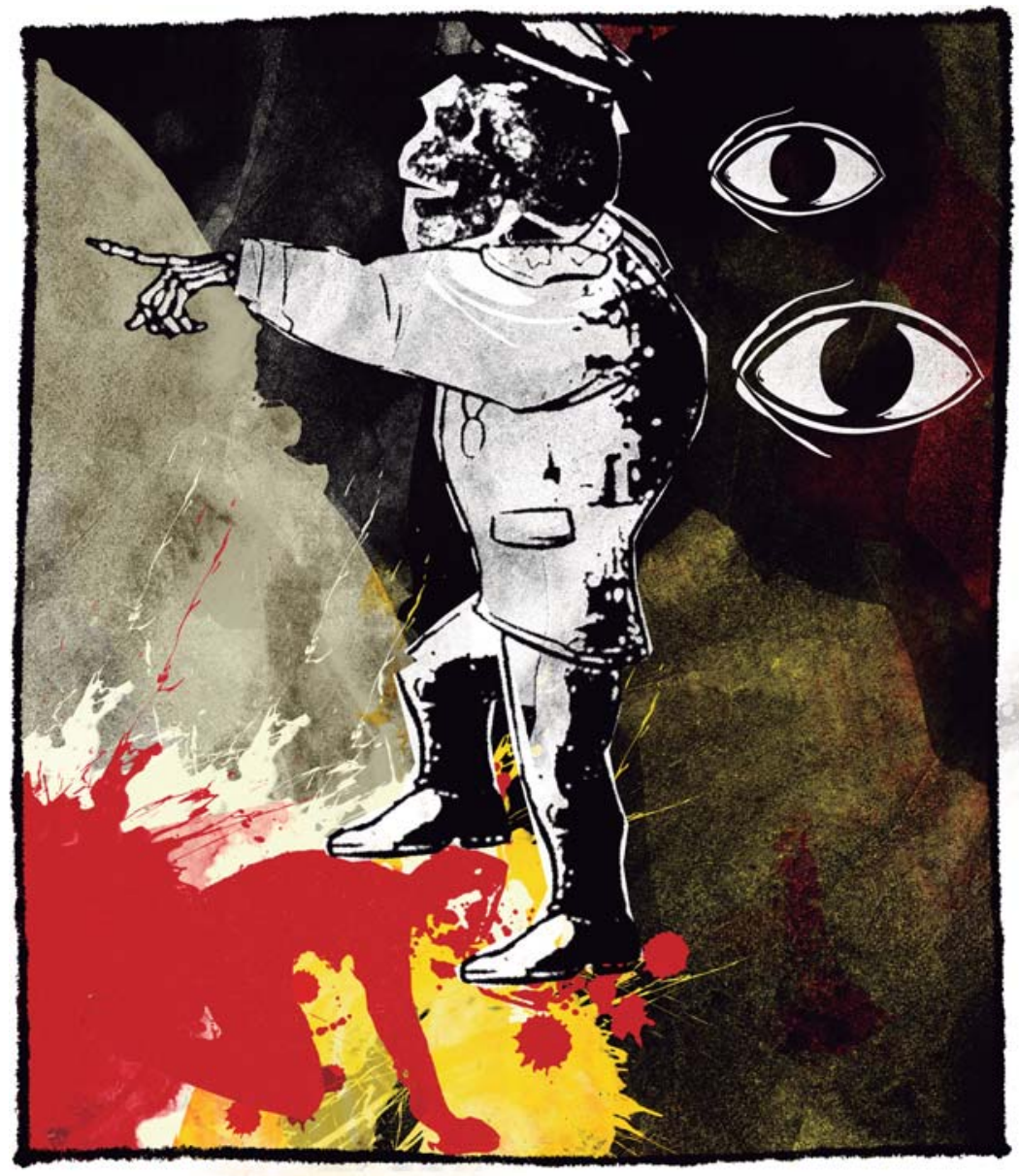

21. Escárnio. Design: Rafael Werkema - ilustração digital/fotocolagem. 


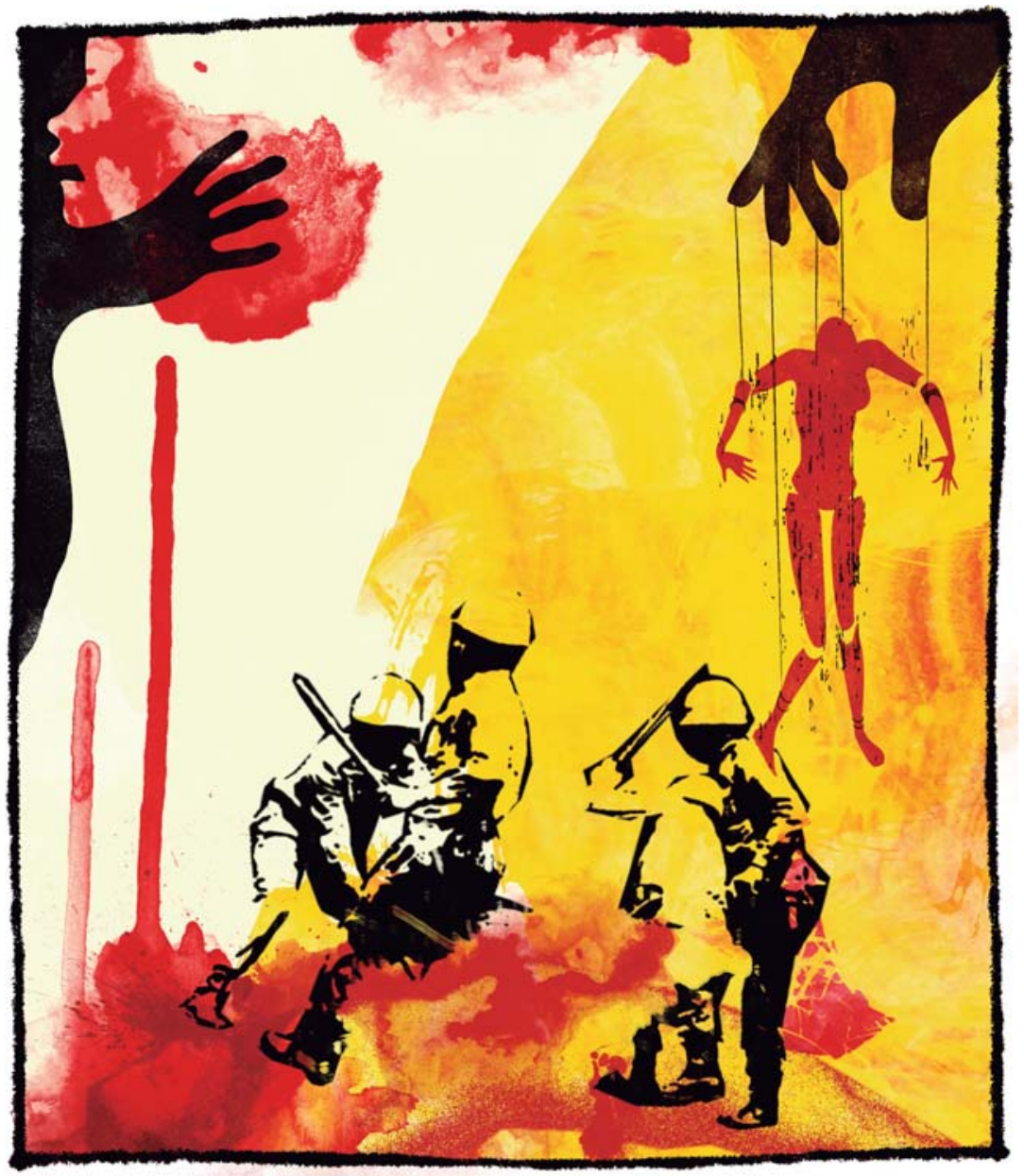

22. Repressão e tortura. Design: Rafael Werkema - ilustração digital/fotocolagem. 
\} MEMÓRIAS E RESISTÊNCIAS DE ASSISTENTES - NEVES, D.; DINIZ, T. M. R. G.; WERKEMA, R. ?

DOI: $10.12957 /$ REP.2017.32733

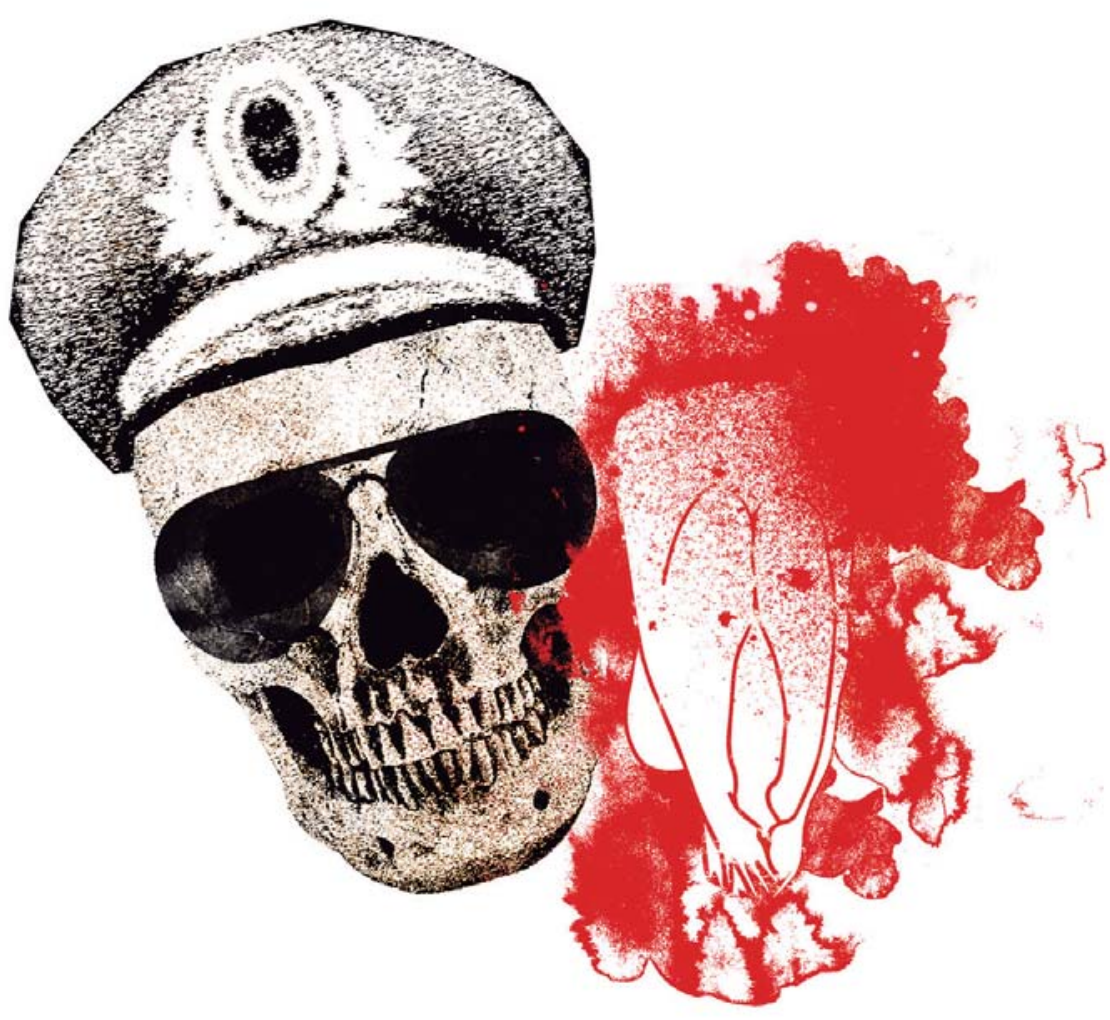

23. O prazer do torturador. Design: Rafael Werkema - ilustração digital/fotocolagem. 


\section{ReVistg all palta}

I MEMÓRIAS E RESISTÊNCIAS DE ASSISTENTES - NEVES, D.; DINIZ, T. M. R. G.; WERKEMA, R. \}

DOI: 10.12957/REP.2017.32733

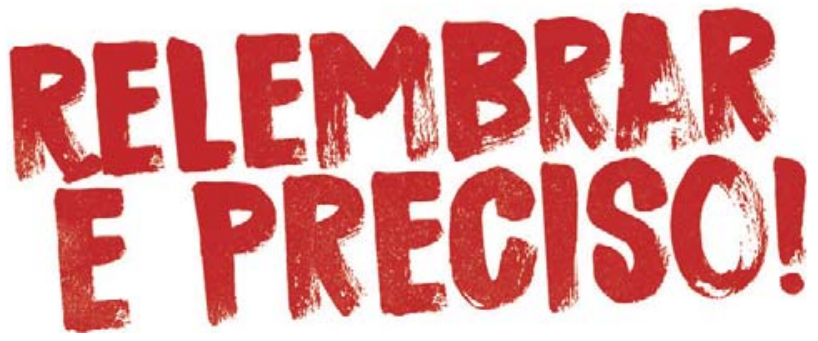

24. Relembrar é preciso

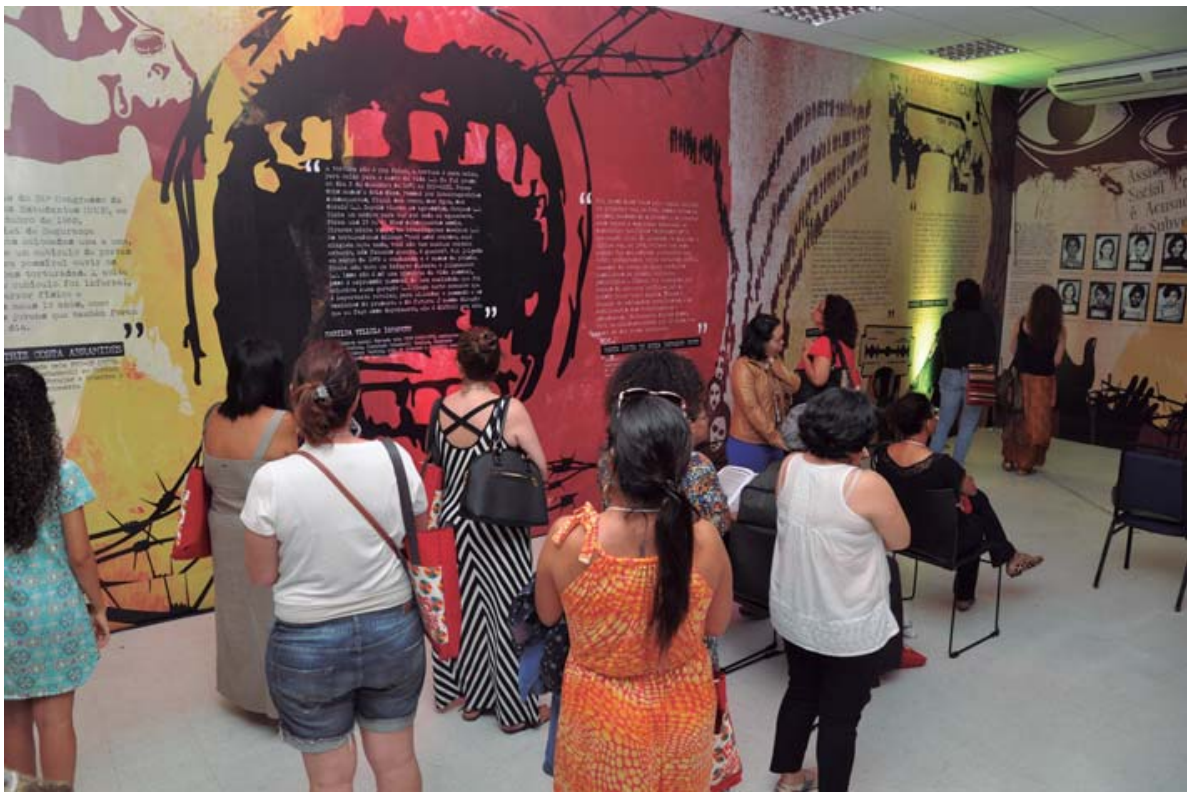

25. A exposição. Foto: Diogo Adjuto

EM PAUTA, Rio de Janeiro - 2º Semestre de 2017 - n. 40, v. 15, p. 332 - 348 


\section{ReVistg all pgUtg}

\} MEMORIAS E RESISTÊNCIAS DE ASSISTENTES - NEVES, D.; DINIZ, T. M. R. G.; WERKEMA, R. \}

DOI: $10.12957 /$ REP.2017.32733

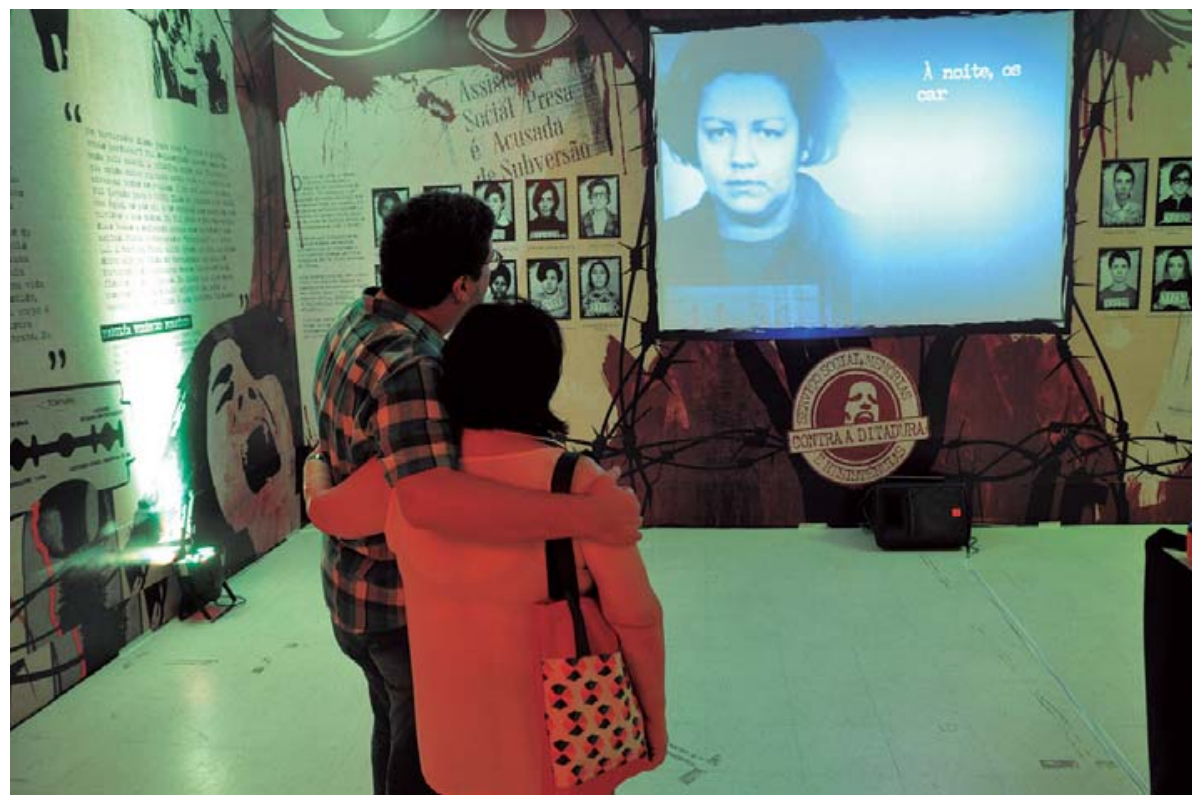

26. A dor da lembrança. Foto: Diogo Adjuto

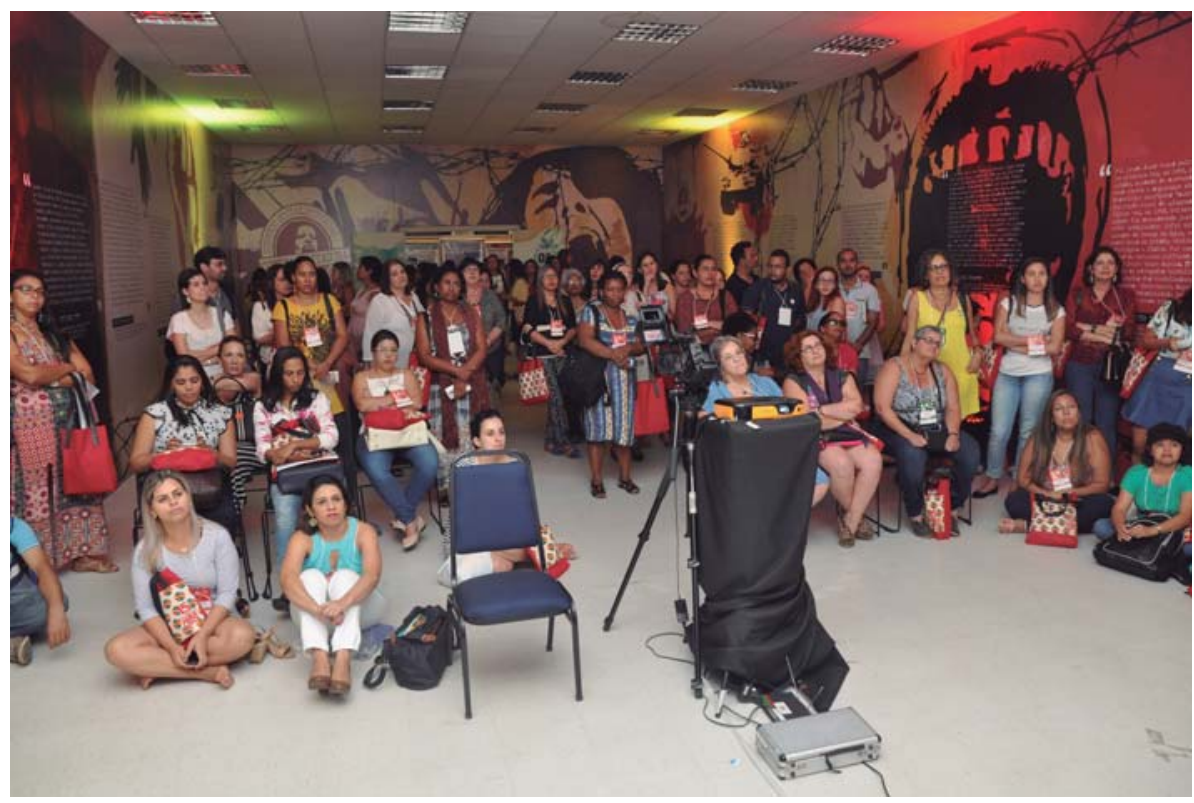

27. Olhares atentos. Foto: Diogo Adjuto

EM PAUTA, Rio de Janeiro - $2^{\circ}$ Semestre de 2017 - n. 40, v. 15, p. 332 - 348 


\section{ApVistg all PaUt?}

I MEMÓRIAS E RESISTÊNCIAS DE ASSISTENTES - NEVES, D.; DINIZ, T. M. R. G.; WERKEMA, R. \} DOI: 10.12957/REP.2017.32733

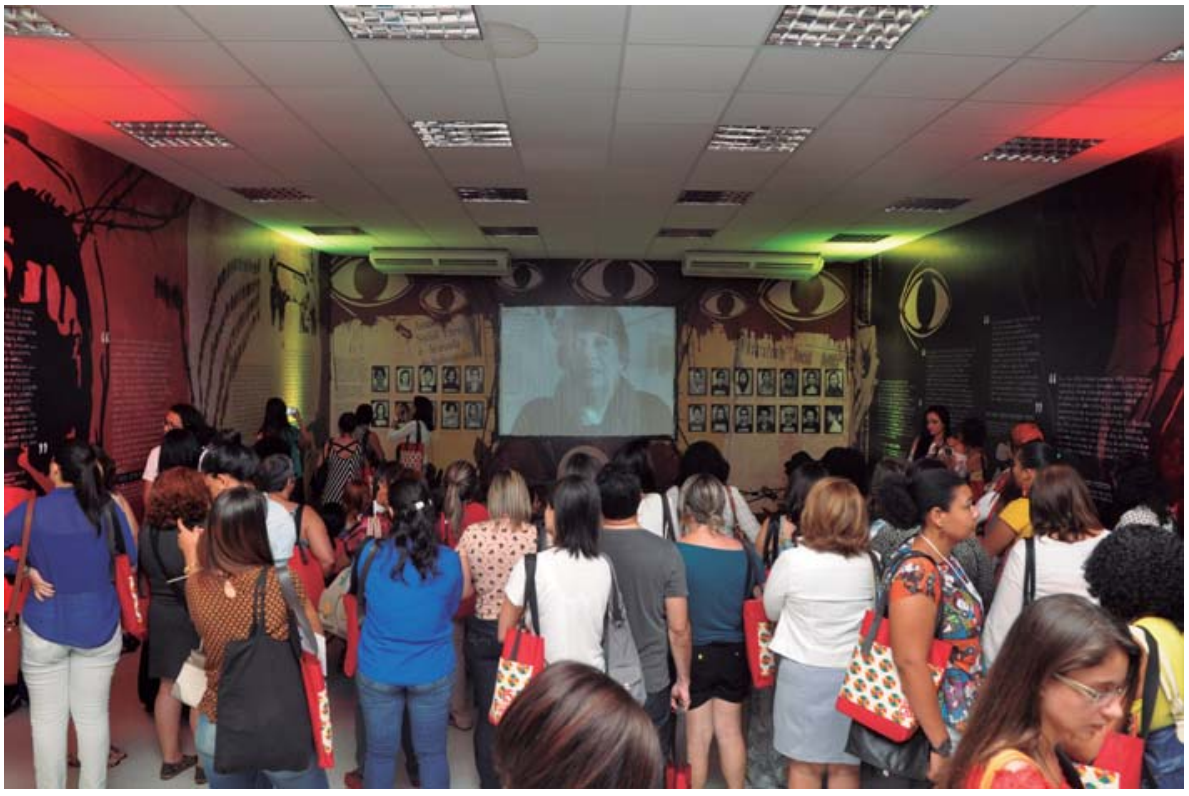

28. Olhar para a memória. Foto: Rafael Werkema

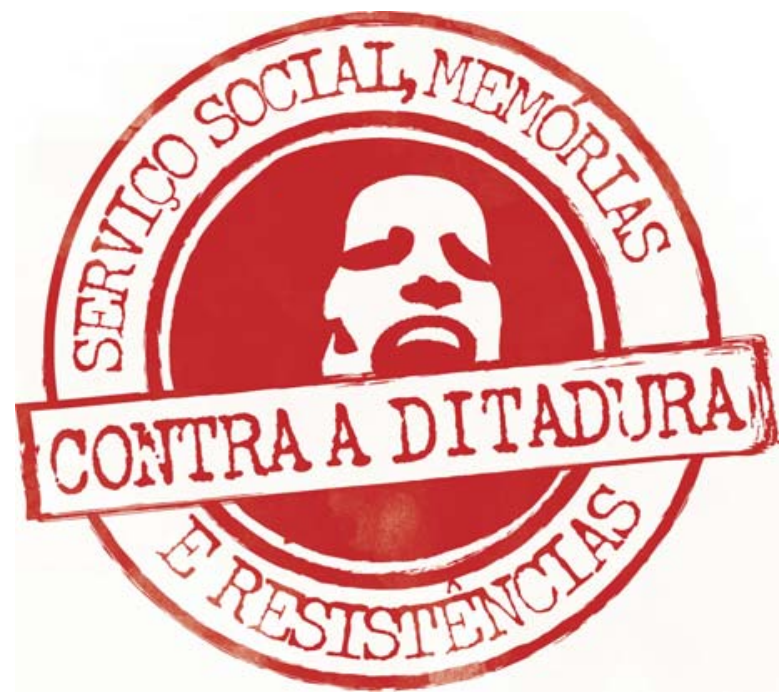

29. Logo do Projeto. Design: Rafael Werkema - ilustração digital

EM PAUTA, Rio de Janeiro - 2 Semestre de 2017 - n. 40, v. 15, p. 332 - 348 